\title{
PENGARUH KEPEMIMPINAN TRANSFORMASIONAL DAN ORGANIZATIONAL CITIZENSHIPBEHAVIOR TERHADAPKEPUASAN KERJA DENGAN KOMITMEN ORGANISASIONAL SEBAGAI VARIABEL INTERVENING
}

\section{THE EFFECT OF TRANSFORMATIONAL AND ORGANIZATIONAL LEADERSHIP CITIZENSHIPBEHAVIOR ON WORK SATISFACTION WITH ORGANIZATIONAL COMMITMENTS AS INTERVENING VARIABLES}

\author{
Nurmala Mustika Dewi ${ }^{1}$, T. Munzir ${ }^{2}$ \\ Program Studi Magister Manajemen Program Pascasarjana Universitas Riau Kepulauan \\ nurmalamustikadewi@gmail.com
}

\begin{abstract}
Abstrak
Penelitian ini bertujuan untuk menganalisis pengaruh Kepemimpinan Transformasional Dan OCB (Organizational Citizenship Behavior) Terhadap Kepuasan Kerja Dengan Komitmen Organisasional Sebagai Variabel Intervening. Metode pengambilan data dalam penelitian ini adalah kuesioner, wawancara, dokumentasi, dan observasi.Teknik pengambilan sampel yang digunakan adalah teknik probability sampling.Populasi yang menjadi objek penelitian ini adalah karyawan PT. PLN (Persero) Rayon Aekkanopan dengan sampel 81 orang karyawan. Pengujian hipotesis dilakukan dengan analisis regresi liniear berganda, analisis jalur, dan uji sobel melalui program SPSS 22.0 for windows. Berdasarkan hasil penelitian dengan taraf signifikansi 5\% diperoleh kesimpulan: (1) terdapat pengaruh positif dan signifikan Kepemimpinan Transformasional terhadap Kepuasan Kerja dengan perbandingan $t_{\text {hitung }}$ dengan $t_{\text {table }}$ sebesar $(3,110>1,991)$ dengan signifikansi 0,03 , perbandingan $\mathrm{F}_{\text {hitung }}$ dengan $\mathrm{F}_{\text {table }}(6,242>2,723)$ dengan signifikansi sebesar $(0,001<$ $0,005)$ memiliki pengaruh langsung sebesar 0,467 dan memiliki pengaruh tidak langsung sebesar $-0,102273$; (2) terdapat pengaruh positif dan signifikan OCB terhadap Kepuasan Kerja dengan perbandingan $t_{\text {hitung }}$ dengan $\mathrm{t}$ table sebesar $(0,916<1,991)$ dengan signifikansi 0,362 , perbandingan $F$ hitung dengan $F$ table $(6,242>2,723)$ dengan signifikansi sebesar $(0,001<0,005)$ memiliki pengaruh langsung sebesar 0,120 dan memiliki pengaruh tidak langsung sebesar -0,02628;(3) terdapat pengaruh positif dan signifikan Kepemimpinan Transformasional terhadap Komitmen Organisasi dengan perbandingan $t$ hitung dengan $t$ table sebesar $(5,065>1,991)$ dengan signifikansi 0,000, perbandingan $\mathrm{F}_{\text {hitung }}$ dengan $\mathrm{F}_{\text {table }}(27,492>2,723)$ dengan signifikansi sebesar $(0,000<$ $0,005)$ memiliki pengaruh langsung sebesar 0,560 ; (4) terdapat pengaruh positif dan signifikan OCB terhadap Komitmen Organisasi dengan perbandingan $t$ hitung dengan $t$ table sebesar $(1,105>1,991)$ dengan signifikansi 0,273 , perbandingan $F_{\text {hitung }}$ dengan $F_{\text {table }}(27,492>2,723)$ dengan signifikansi sebesar $(0,000<0,005)$ memiliki pengaruh langsung sebesar 0,122; (5) terdapat pengaruh negatif Komimen Organisasi terhadap Kepuasan Kerja dengan perbandingan $t_{\text {hitung }}$ dengan $t_{\text {table }}$ sebesar $(-1,643<1,991)$ dengan signifikansi 0,104 , perbandingan $\mathrm{F}$ hitung dengan $F_{\text {table }}(6,242>2,723)$ dengan signifikansi sebesar $(0,001<0,005)$ memiliki pengaruh langsung sebesar-0,219; (6) terdapat pengaruh positif dan signifikan Kepemimpinan Transformasional dan OCB terhadap Kepuasan Kerja dengan perbandingan $\mathrm{F}_{\text {hitung }}$ dengan $\mathrm{F}_{\text {table }}(6,242>2,723)$ dengan signifikansi sebesar $(0,001<$ 0,005) (7) Variable Komitmen Organisasi tidak memediasi variable Kepemimpinan Transformasional dan variable OCB (Organizational Citizenship Behavior) terhadap Kepuasan Kerja Karyawan.
\end{abstract}

Kata kunci: Kepemimpinan Transformasional, OCB (Organizational Citizenship Behavior), Kepuasan Kerja, Komitmen Organisasi

\begin{abstract}
This research purposed to analyze the effect of transformational leadership and organizational citizenship behavior to job satisfaction and organizational commitment as intervening variable.

Data retrieval method in this research is a questionnaire. The sampling technique used is the technique probably sampling. Population which is the object of this study are employees PT. PLN(Persero)Rayon Aekkanopan with a sample of 81 employees. Hypothesis testing is done by multiple linear regression analysis, path analysis, and test sobel through the program SPSS 22,0 for windows.

The result of this research prove and conclude that: (1) there is a positive and significant effect of transformational leadership on job satisfaction by comparison $t$ count with $t$ table of $(3,110>1,991)$ with significant 0,03 comparison $F_{\text {count }}$ with $F_{\text {table }}$ of $(6,242>2,723)$ with significant $(0,001<0,005)$ has a direct effect of 0,467 and have the indirect effect of -0,102273;(2)there is a positive and significant effect
\end{abstract}


OCB(Organizational Citizenship Behavior) on job satisfaction by comparison $t$ count with $t$ table of $(0,916<$ $1,991)$ with significant 0,362 comparison $F_{\text {count }}$ with $F_{\text {table }}$ of $(6,242>2,723)$ with significant $(0,001<0,005)$ has a direct effect of 0,120 and have the indirect effect of -0,02628;(3)there is a positive and significant effect of transformational leadership on organizational commitment by comparison $t_{\text {count }}$ with $t_{\text {table }}$ of $(5,065>1,991)$ with significant 0,000 comparison $F_{\text {count }}$ with $F_{\text {table }}$ of $(27,492>2,723)$ with significant $(0,000<0,005)$ has a direct effect of 0,560;(4)there is a positive and significant effect of OCB(Organizational Citizenship Behavior) on organizational commitment by comparison $t$ count with $t$ table of $(1,105>1,991)$ with significant 0,273 comparison $F_{\text {count }}$ with $F_{\text {table }}$ of $(27,492>2,723)$ with significant $(0,000<0,005)$ has a direct effect of 0,$122 ;(5)$ there is a negative effect on job satisfaction organizational commitment by comparison $t_{\text {count }}$ with $t_{\text {table }}$ of $(-1,643<1,991)$ with significant 0,104 , comparison $F_{\text {count }}$ with $F_{\text {table }}$ of $(6,242>2,723)$ with significant $(0,001<$ $0,005)$ has a direct effect of-0,219;(6) there is a positive and significant effect of transformational leadership and OCB (Organizational Citizenship Behavior) to job satisfaction comparison $F$ count with $F_{\text {table }}$ of $(6,242>$ $2,723)$ with significant $(0,001<0,005)$; (7)variable organizational commitment does not mediate variable transformational leadership and OCB (Organizational Citizenship Behavior) to job satisfaction.

Keyword: Transformasional Leadership, OCB (Organizational Citizenship Behavior), Job Satisfaction, Organizational Commitment

\section{PENDAHULUAN}

Perusahaan Listrik Negara (PLN) atau nama resminya adalah PT. PLN (Persero) adalah sebuah BUMN (Badan Usaha Milik Negara) yang mengurusi semua aspek kelistrikanyang ada di Indonesia. PT. PLN (Persero) menyelenggarakan usaha penyediaan tenaga listrik bagi kepentingan umum dalam jumlah dan mutu yang memadai serta memupuk keuntungan dan melaksanakan penugasan pemerintah di bidang ketenagalistrikan dalam rangka menunjang pembangunan dengan menerapkan prinsip-prinsip perseroan terbatas.PT. PLN (Persero) memiliki slogan "Listrik Untuk Kehidupan Yang Lebih Baik".

Kelangsungan hidup dan perkembangan dari suatu perusahaan tidak hanya bergantung pada baik buruknya pengelolaan keuangan perusahaan, pelayanan, promosi, dan pemasaran serta tingkat kualitas produknya, tetapi ditentukan dari keberhasilannya dalam mengelolah sumber daya manusia.Mengelolah sumber daya manusia dalam organisasi/perusahaan bukan hal yang mudah karena melibatkan berbagai elemen didalamnya, yaitu karyawan, pimpinan, maupun sistem itu sendiri. Adanya Kepemimpinan Transformasional yang baik serta OCB (Organizational Citizenship Behavior) yang akan berpengaruh terhadap Kepuasan Kerja karyawan dalam bekerja dan pada akhirnya akan mempengaruhi Komitmen Organisasional karyawan guna meningkatkan produktivitas perusahaan.

Kepuasan Kerja adalah sikap emosional yang menyenangkan dan mencintai pekerjaannya (Hasibuan, 2009: 202). Sikap ini dicerminkan oleh moral kerja, kedisplinan, dan prestasi kerja.Kepuasan Kerja dinikmati dalam pekerjaan, luar pekerjaan, dan kombinasi dalam dan luar pekerjaan. Apabila Kepuasan Kerja yang dirasakan oleh karyawan rendah akan memberikan dampak negatif terhadap perusahaan karena komitmen organisasi tersebut 
akan menurun. Fenomena penelitian tentang Kepuasan Kerja karyawan pada PT. PLN (Persero) Rayon Aek Kanopan adalah karyawan merasa ketidakpuasan kerja dibuktikan dengan karyawan cenderung monoton, karyawan belum memandang pekerjaannya sebagai hal yang menyenangkan atau sebagai hal yang membosankan serta karyawan tersebut bekerja dalam keadaan bosan, karyawan tidak bersemangat dalam bekerja, pemanfaatan waktu kerja yang kurang optimal, serta banyak karyawan yang terlambat masuk kerja. Karyawan merasa puas dengan fasilitas kerja dan kondisi kerja yang ada di PT. PLN (Rayon) Aek Kanopan, jika mencapai target didalam pekerjaan selama satu semester maka karyawan akan diberikan bonus (imbalan), rekan kerja yang solid dan kekeluargaan yang mendorong terciptanya Kepuasan Kerja di lingkungan PT. PLN (Rayon) Aek Kanopan, sikap dan motivasi dari manajer rayon merupakan salah satu yang menciptakan Kepuasan Kerja karyawan PT. PLN (Rayon) Aek Kanopan.

Kepemimpinan Transformasional memiliki perubahan peran penting dalam sebuah organisasi sebagai penentu keberhasilan dalam pencapaian misi, visi, dan tujuan suatu organisasi. Kepemimpinan yang dibutuhkan adalah yang mampu mengarahkan dan menggunakan SDM yang tersedia secara optimal, sehingga karyawan akan merasa nyaman dalam bekerja dan akan berpengaruh terhadap kepuasan kerja dan komitmen organisasional. Fenomena yang terjadi mengenai kepemimpinan transformasional pada PT. PLN(Persero) Rayon Aek Kanopan ditunjukkan bahwa kepemimpinan di PT. PLN (Persero) Rayon Aek Kanopan menciptakan bawahan mempercayai pemimpin karena pemimpin dianggap mempunyai pandangan, nilai dan tujuan yang dianggap benar, misalnya manager rayon membuat acara penghargaan (reward) yang dilaksanakan pada Jumat, 3 Februari 2017 yaitu membuat reward (penghargaan) kepada karyawan yang memiliki prestasi selama satu semester. Pemimpin merupakan (problem solver) yang mampu menyelesaikan masalah yang tak bisa diselesaikan oleh karyawan sebagai contoh ada pelanggan PLN yang marah saat melakukan pengaduan terjadi Tusbung (pemutus hubungan listrik) dirumah beliau namun dengan bijaksana manajer rayon menjelaskan alasan mengapa terjadi tusbung dirumah pelanggan tersebut.

OCB (Organizational Citizenship Behavior) adalah perilaku kebebasan menentukan yang bukan bagian dari persyaratan pekerjaan formal karyawan, tetapi berkontribusi pada lingkungan psikologis dan sosial tempat kerja (Robbins Dan Judge, 2015:19). OCB (Organizational Citizenship Behavior) menggambarkan segala kegiatan atau aktivitas yang 
bukan merupakan tugas utama dari karyawan namun apabila dikerjakan akan memberikan dampak positif bagi karyawan dan perusahaan. Permasalahan OCB (Organizational Citizenship Behavior) pada PT. PLN (Persero) Rayon Aek Kanopan yaitu ada beberapa karyawan yang belum pernah mengerjakan pekerjaandiluar pekerjaan pokoknya dan apabila ada karyawan menemui masalah, karyawan lain hanya memberikan saran atau pendapat saja namun tidak pernah membantu secara langsung atau secara nyata dalam pekerjaan. Selain itu ada karyawan yang hanya menjalankan tugasnya dengan cara menunggu perintah dariatasannya saja, dengan kata lain karyawan tersebut tidak mempunyai inisiatifsendiri untuk melakukan pekerjaannya dan melakukan pekerjaan lain atau diluartugas pokoknya. Namun, karyawan senior membantu karyawan junior apabila kesukaran dalam memecahkan masalah tanpa ada instruksi dari manager dan mendapatkan imbalan dalam bentuk apapun. Karyawan yang memiliki OCB (Organizational Citizenship Behavior) tentunya memberi kontribusi melebihi apa yang diinginkan perusahaan. Apabila seorang karyawan tidak menunjukkan sikap ekstra peran serta yang besar pada perusahaan pastinya karyawan tersebut tidak mengindikasikan terciptanya OCB (Organizational Citizenship Behavior) pada diri karyawan PT. PLN (Persero) Aek Kanopan.

Komitmen terhadap organisasi berguna untuk memahami dedikasi bawahan terhadap organisasi kerjanya (Yeh dan Hong, 2012:124). Ini artinya bahwa seorang karyawan yang mempunyai komitmen terhadap organisasi, memaknai kerja dengan hal yang luhur mengindikasikan bahwasanya mereka dekat dengan kedisiplinan kerja yang akan dicapai dan dekat dengan perasaan puas terhadap pekerjaan yang dicapainya. Pada PT. PLN (Persero) Rayon Aek Kanopan, masih kurangnya komitmen karyawan ini terbukti dengan masih ada terjadi pelanggaran dalam hal jam masuk kerja artinya banyak karyawan yang tidak tepat waktu (tidak disiplin waktu) tidak sesuai dengan jam masuk yang sudah ditetapkan yaitu Senin s/d Kamis masuk pkl. 08:00-16:30 WIB, jumat pkl. 08:00-17:00 WIB, kurangnya loyalitas karyawan terhadap perusahaan ditunjukkan dengan masih ada karyawan yang bolos kerja disaat manager rayon tidak ada dikantor, serta masih ada karyawan yang hanya akan menyelesaikan pekerjaan jika ada manager dikantor. Namun, yang menjadi bukti terciptanya komitmen organisasional karyawan di PT. PLN (Rayon) Aek Kanopan dibuktikan bahwa kinerja selama satu semester menuai hasil Runner Up ditingkat PT. PLN (Area) Rantau Prapat serta loyalitas karyawan terhadap perusahaan dapat dilihat dari cara menyelesaikan tugas sesuai dengan standar yang ditentukan dalam perusahaan. 


\section{Tujuan Penelitian}

1. Untuk Menganalisis Pengaruh Kepemimpinan Transformasional Terhadap Kepuasan Kerja(Studi Empiris Pada PT. PLN (Persero) Rayon Aek Kanopan).

2. Untuk Menganalisis Pengaruh OCB (Organizational Citizenship Behavior) Terhadap Kepuasan Kerja (Studi Empiris Pada PT. PLN (Persero) Rayon Aek Kanopan).

3. Untuk Menganalisis Pengaruh Kepemimpinan Transformasional Terhadap Komitmen Organisasional (Studi Empiris Pada PT. PLN (Persero) Rayon Aek Kanopan).

4. Untuk Menganalisis Pengaruh OCB (Organizational Citizenship Behavior) Terhadap Komitmen Organisasional (Studi Empiris Pada PT. PLN (Persero) Rayon Aek Kanopan).

5. Untuk Menganalisis Pengaruh Komitmen Organisasional Terhadap Kepuasan Kerja (Studi Empiris Pada PT. PLN (Persero) Rayon Aek Kanopan).

6. Untuk Menganalisis Pengaruh Kepemimpinan Transformasional dan OCB (Organizational Citizenship Behavior) Terhadap Kepuasan Kerja (Studi Empiris Pada PT. PLN (Persero) Rayon Aek Kanopan).

7. Untuk Menganalisis Pengaruh Kepemimpinan Transformasional dan OCB (Organizational Citizenship Behavior) Terhadap Kepuasan Kerja Dengan Komitmen Organisasional Sebagai Variabel Intervening (Studi Empiris Pada PT. PLN (Persero) Rayon Aek Kanopan).

\section{TINJAUAN PUSTAKA}

\section{Kepemimpinan Transformasional}

Kepemimpinan Transformasional menurut (Robbins dan Judge, 2008:91) mengemukakan bahwa "Kepemimpinan Transformasional adalah pemimpin yang menginspirasi para pengikutnya untuk menyampingkan kepentingan pribadi mereka demi kebaikan organisasi dan mereka mampu memiliki pengaruh yang luar biasa pada diri pengikutnya".

\section{OCB (Organizational Citizenship Behavior)}

“OCB (Organizational Citizenship Behavior) adalah perilaku atas kehendak sendiri yang bukan menjadi bagian dari tuntutan kerja formal tetapi mendorong efektivitas fungsi organisasi” (Robins dan Coulter, 2010: 36). 


\section{Kepuasan Kerja}

Kepuasan Kerja menurut Mathis dan Jackson (dalam Sopiah, 2008 : 170) mengemukakan, "Job satisfaction is a positive emotional state resulting one's job experience." (Kepuasan kerja merupakan pernyataan emosional yang positif yang merupakan hasil evaluasi dari pengalaman kerja). Menurut Sopiah (2008:170) kepuasan kerja adalah suatu tanggapan emosional seseorang terhadap situasi dan kondisi kerja.

\section{Komitmen Organisasi}

Komitmen Organisasi menurut Porter et al. (dalam Mohammed dan Annisa, 2012;67), "komitmen organisasi adalah kesiapan karyawan untuk menerapkan peningkatan upaya kerja keras atas nama perusahaan, penerimaan tujuan, standar, prinsip, etika, nilai, dan memiliki aspirasi yang kokoh untuk tetap tinggal dengan organisasi”.

\section{Metode Penelitian}

Dalam penelitian ini, penentuan objek penelitian menggunakan teknik Proportional Random Sampling. Yaitu teknik pengambilan sampel dimana semua anggota mempunyai kesempatan bersama yang sama untuk dijadikan sampel, sesuai dengan proporsinya, banyak atau sedikit populasi, (Sani, 2010:288). Agar sampel yang digunakan dapat dikatakan representative maka dalam penelitian ini ditentukan dengan rumus Slovin (Sani, 2010: 288).

Keterangan:

$$
n=\frac{N}{N(d)^{2}+1}
$$

$$
\begin{aligned}
& \mathrm{N}=\text { populasi } \\
& \mathrm{n}=\text { sampel } \\
& \mathrm{d}=\quad \text { nilai presisi } 95 \% \text { atau sig }=0,05 \text { (Riduwan, 2009: 42) } \\
& n=\frac{102}{102(0,05)^{2}+1} \\
& =\frac{102}{102(0,0025)+1} \\
& =\frac{102}{1,255}=81,27
\end{aligned}
$$

Jumlah keseluruhan karyawan atau populasi pada pada PT. PLN (Persero) Rayon Aek Kanopan sebanyak 102 orang. Berdasarkan rumus tersebut maka diperoleh jumlah sampel pada penelitian ini sebanyak 81 orang.

Variabel penelitian adalah suatu atribut atau sifat atau nilai dari orang, objek atau kegiatan yang mempunyai variasi tertentu yang ditetapkan oleh peneliti untuk dipelajari dan ditarik kesimpulannya (Sugiono, 2013:2). Dalam penelitian ini peneliti menggunakan tiga jenis variabel, yaitu variabel Independent, variabel Dependent, dan variabel Intervening. 
Tabel 1 Definisi Operasional Variabel

\begin{tabular}{|c|c|c|c|c|}
\hline Variabel & Definisi Operasional & Dimensi & Indikator & Skala \\
\hline \multirow{4}{*}{$\begin{array}{c}\text { Kepemimpinan } \\
\text { transformasional } \\
\left(\mathrm{X}_{1}\right)\end{array}$} & \multirow{4}{*}{$\begin{array}{l}\text { Kepemimpinan } \\
\text { transformasional mengacu } \\
\text { kepada pemimpin yang } \\
\text { menggerakkan pengikutnya } \\
\text { melampaui kepentingan } \\
\text { pribadinya melalui } \\
\text { pengaruh ideal atau } \\
\text { kharisma, inspirasi, } \\
\text { stimulasi intelektual, dan } \\
\text { pertimbangan bersifat } \\
\text { individual. }\end{array}$} & $\begin{array}{l}\text { 1. Idealized } \\
\text { 2. Influence } \\
\text { (karisma). }\end{array}$ & $\begin{array}{l}\text { a. Rasa hormat. } \\
\text { b. Percaya diri. } \\
\text { c. Perilaku } \\
\text { moral. } \\
\text { d. Saling berbagi. } \\
\text { e. Menjadi } \\
\text { teladan }\end{array}$ & \multirow{4}{*}{ Likert } \\
\hline & & $\begin{array}{l}\text { 3. Motivasiins } \\
\text { pirasional. }\end{array}$ & $\begin{array}{ll}\text { f. } & \text { Antusiasme. } \\
\text { g. } & \text { Optimisme. }\end{array}$ & \\
\hline & & $\begin{array}{l}\text { 4. Stimulasi } \\
\text { intelektual. }\end{array}$ & $\begin{array}{l}\text { h. Ide baru. } \\
\text { i. Solusi kreatif. }\end{array}$ & \\
\hline & & $\begin{array}{l}\text { 5. Pertimbanga } \\
\text { n Individual. }\end{array}$ & $\begin{array}{ll}\text { j. } & \text { Mendengarkan } \\
\text { k. } & \text { Perhatian } \\
& \text { khusus } \\
& \text { terhadap } \\
& \text { kebutuhan } \\
& \text { prestasi. } \\
\text { 1. } & \text { Mengajari dan } \\
& \text { melatih. } \\
\end{array}$ & \\
\hline \multirow{5}{*}{$\begin{array}{c}\text { OCB } \\
\text { (Organizational } \\
\text { Citizenship } \\
\text { Behavior) } \\
\left(\mathrm{X}_{2}\right)\end{array}$} & \multirow{5}{*}{$\begin{array}{l}\text { Kontribusi seseorang } \\
\text { individu yang melebihi } \\
\text { tuntutan peran ditempat } \\
\text { kerja dan diberi } \\
\text { penghargaan berdasarkan } \\
\text { hasil kinerja individu. }\end{array}$} & $\begin{array}{l}\text { 1. Altruism } \\
\text { (helping) }\end{array}$ & $\begin{array}{ll}\text { a. } & \text { Bantuan/pertol } \\
\text { ongan. } \\
\text { b. Bersifat } \\
\text { sukarela. }\end{array}$ & \multirow{5}{*}{ Likert } \\
\hline & & $\begin{array}{l}\text { 2. Conscientio } \\
\text { sness (sifat } \\
\text { berhati-hati) }\end{array}$ & $\begin{array}{ll}\text { c. } & \text { Melebihi tugas } \\
\text { pokok. } \\
\text { d. Tidak } \\
\text { diperintah } \\
\text { secara formal. }\end{array}$ & \\
\hline & & $\begin{array}{ll}\text { 3. } & \text { Sportsmans } \\
\text { hip (sikap } \\
\text { sportif) }\end{array}$ & $\begin{aligned} & \text { e. } \text { Sikap } \\
& \text { toleransi. } \\
& \text { f. } \text { Mudah } \\
& \text { beradaptasi. } \\
&\end{aligned}$ & \\
\hline & & 4. $\begin{array}{l}\text { Courtesy } \\
\text { (kebaikan) }\end{array}$ & $\begin{array}{ll}\text { g. } & \begin{array}{l}\text { Problem } \\
\text { solver } \\
\text { (pemecah }\end{array} \\
\text { masalah) } \\
\text { h. } & \begin{array}{l}\text { Make Decision } \\
\text { (membuat } \\
\text { keputusan }\end{array} \\
\end{array}$ & \\
\hline & & $\begin{array}{l}\text { 5. Civic Virtue } \\
\text { (mendukung } \\
\text { fungsi- } \\
\text { fungsi) }\end{array}$ & $\begin{array}{ll}\text { i. } & \text { Partisipasi } \\
\text { aktif. } \\
\text { j. } & \text { Mendukung } \\
& \text { fungsi } \\
& \text { administrasi. }\end{array}$ & \\
\hline
\end{tabular}




\begin{tabular}{|c|c|c|c|c|}
\hline $\begin{array}{c}\text { Kepuasan Kerja } \\
\text { (Y) }\end{array}$ & $\begin{array}{l}\text { Kepuasan kerja merupakan } \\
\text { sikap dan perasaan } \\
\text { pegawai, karyawan atau } \\
\text { pekerja terhadap pekerjaan } \\
\text { yang dilakukannya, } \\
\text { lingkungan kerjanya, } \\
\text { ganjaran atau imbalan yang } \\
\text { diterimanya dan penilaian } \\
\text { terhadap hasil } \\
\text { pekerjaannya. }\end{array}$ & & $\begin{array}{l}\text { 1. } \begin{array}{l}\text { Kondisi Kerja } \\
\text { (work }\end{array} \\
\text { condition). } \\
\text { 2. Imbalan (pay). } \\
\text { 3. Tanggung } \\
\text { jawab } \\
\text { (responsibility. } \\
\text { 4. Kenaikan } \\
\text { jabatan } \\
\text { (advancement) } \\
\text { 5. Keamanan } \\
\text { (security) } \\
\text { 6. Penghargaan } \\
\text { (recognition) } \\
\text { 7. Kompensasi. }\end{array}$ & Likert \\
\hline \multirow{3}{*}{$\begin{array}{l}\text { Komitmen } \\
\text { Organisasi } \\
\quad(Z)\end{array}$} & \multirow[t]{3}{*}{$\begin{array}{l}\text { Komitmen organisasi } \\
\text { adalah suatu keadaan } \\
\text { dimana seseorang } \\
\text { karyawan memihak } \\
\text { organisasi tertentu serta } \\
\text { tujuan tujuan dan } \\
\text { keinginannya untuk } \\
\text { mempertahankan } \\
\text { keanggotaan dalam } \\
\text { organisasi tersebut. }\end{array}$} & $\begin{array}{l}\text { 1. Komitmen } \\
\text { Afektif } \\
\text { (affective } \\
\text { commitmen) }\end{array}$ & 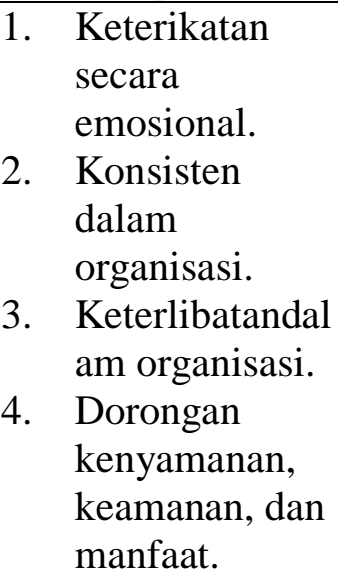 & \\
\hline & & $\begin{array}{l}\text { 2. Komitmen } \\
\text { berkelanjuta } \\
\mathrm{n} \\
\text { (continuanc } \\
e \\
\text { commitment } \\
\quad \text { ) }\end{array}$ & $\begin{array}{ll}\text { a. Sumbangan. } \\
\text { b. Dedikasi. } \\
\text { c. Keterkaitan } \\
\text { secara } \\
\text { psikologis. }\end{array}$ & \\
\hline & & $\begin{array}{l}\text { 3. Komitmen } \\
\text { Normatif } \\
\text { (normative } \\
\text { commitment } \\
\text { ) }\end{array}$ & $\begin{array}{l}\text { 1. Perasaan } \\
\text { kewajiban/keh } \\
\text { arusan moral. } \\
\text { 2. Perasaan } \\
\text { bertahan. } \\
\text { 3. Keterkaitan } \\
\text { secara } \\
\text { psikologis. }\end{array}$ & Likert \\
\hline
\end{tabular}

Sumber: (Robbins dan Judge, 2008:91), (Robins dan Coulter, 2010:36), Mathis dan Jackson (dalam Sopiah, 2008:170), Porter et al. (dalam Mohammed dan Annisa, 2012:67). 


\section{PEMBAHASAN}

\section{Uji Validitas}

Uji validitas digunakan untuk mengetahui valid atau tidaknya kuesioner yang dibagikan.Kuesioner dikatakan valid apabila mampu mengungkapkan nilai variabel yang diteliti. Menurut (Sugiyono, 2013: 348) instrument yang valid adalah instrument yang dapat digunakan untuk mengukur apa yang hendak diukur. Alat analisis yang digunakan mengukur tingkat validitas data adalah dengan koefisien korelasi menggunakan bantuan software SPSS 22.0 for windows. Hasil uji validitas instrumen disajikan pada tabel berikut ini.

Tabel 2 Hasil uji validitas instrument variabel kepemimpinan transformasional $\left(X_{1}\right)$

\begin{tabular}{|c|c|c|c|c|}
\hline Variabel & Indikator & r Hitung & r Tabel & Keterangan \\
\hline \multirow{4}{*}{$\begin{array}{c}\text { Kepemimpinan } \\
\text { Transformasional } \\
\left(\mathrm{X}_{1}\right)\end{array}$} & Keptrans 1 & 0,520 & 0,2185 & Valid \\
\cline { 2 - 5 } & Keptrans 2 & 0,630 & 0,2185 & Valid \\
\cline { 2 - 5 } & Keptrans 3 & 0,554 & 0,2185 & Valid \\
\cline { 2 - 5 } & Keptrans 4 & 0,418 & 0,2185 & Valid \\
\cline { 2 - 5 } & Keptrans 5 & 0,502 & 0,2185 & Valid \\
\cline { 2 - 5 } & Keptrans 6 & 0,562 & 0,2185 & Valid \\
\cline { 2 - 5 } & Keptrans 7 & 0,433 & 0,2185 & Valid \\
\cline { 2 - 5 } & Keptrans 8 & 0,525 & 0,2185 & Valid \\
\cline { 2 - 5 } & Keptrans 9 & 0,395 & 0,2185 & Valid \\
\cline { 2 - 5 } & Keptrans 10 & 0,557 & 0,2185 & Valid \\
\cline { 2 - 5 } & Keptrans 11 & 0,512 & 0,2185 & Valid \\
\cline { 2 - 5 } & Keptrans 12 & 0,666 & 0,2185 & Valid \\
\hline
\end{tabular}

Sumber: Hasil penelitian, 2017

Berdasarkan hasil pengujian uji validitas terhadap variabel Kepemimpinan Transformasional $\left(\mathrm{X}_{1}\right)$ yang terdiri 12 pernyataan dapat diketahui bahwa semua butir pernyataan dinyatakan valid.

Tabel 3 Hasil uji validitas instrument variabel OCB (Organizational Citizenship Behavior $)\left(\mathbf{X}_{2}\right)$

\begin{tabular}{|c|c|c|c|c|}
\hline Variabel & Indikator & r hitung & r table & Keterangan \\
\hline \multirow{5}{*}{\begin{tabular}{c} 
OCB \\
(Organizational \\
Citizenship \\
Behavior) \\
\cline { 2 - 5 }$\left(\mathrm{X}_{2}\right)$
\end{tabular}} & OCB 1 & 0,744 & 0,2185 & Valid \\
\cline { 2 - 5 } & OCB 2 & 0,552 & 0,2185 & Valid \\
\cline { 2 - 5 } & OCB 3 & 0,610 & 0,2185 & Valid \\
\cline { 2 - 5 } & OCB 4 & 0,704 & 0,2185 & Valid \\
\cline { 2 - 5 } & OCB 5 & 0,690 & 0,2185 & Valid \\
\cline { 2 - 5 } & OCB 6 & 0,747 & 0,2185 & Valid \\
\cline { 2 - 5 } & OCB 7 & 0,675 & 0,2185 & Valid \\
\cline { 2 - 5 } & OCB 8 & 0,703 & 0,2185 & Valid \\
\cline { 2 - 5 } & OCB 9 & 0,568 & 0,2185 & Valid \\
\cline { 2 - 5 } & OCB 10 & 0,465 & 0,2185 & Valid \\
\hline
\end{tabular}

Sumber: Hasil penelitian, 2017 
Berdasarkan hasil pengujian uji validitas terhadap variabel OCB (Organizational Citizenship Behavior $)\left(\mathrm{X}_{2}\right)$ yang terdiri 10 pernyataan dapat diketahui bahwa semua butir pernyataan dinyatakan valid.

Tabel 4 Hasil uji validitas instrument variabel kepuasan kerja (Y)

\begin{tabular}{|c|c|c|c|c|}
\hline Variabel & Indikator & r hitung & r table & Keterangan \\
\hline \multirow{4}{*}{$\begin{array}{c}\text { Kepuasan } \\
\text { Kerja }\end{array}$} & Kep 1 & 0,663 & 0,2185 & Valid \\
\cline { 2 - 5 } (Y) & Kep 2 & 0,764 & 0,2185 & Valid \\
\cline { 2 - 5 } & Kep 3 & 0,784 & 0,2185 & Valid \\
\cline { 2 - 5 } & Kep 4 & 0,659 & 0,2185 & Valid \\
\cline { 2 - 5 } & Kep 5 & 0,692 & 0,2185 & Valid \\
\cline { 2 - 5 } & Kep 6 & 0,645 & 0,2185 & Valid \\
\cline { 2 - 5 } & Kep 7 & 0,429 & 0,2185 & Valid \\
\hline
\end{tabular}

Sumber: Hasil penelitian, 2017

Berdasarkan hasil pengujian uji validitas terhadap variabel Kepuasan Kerja (Y) yang terdiri 7 pernyataan dapat diketahui bahwa semua butir pernyataan dinyatakan valid.

Tabel 5 Hasil uji validitas instrument variabel komitmen organisasi $(Z)$

\begin{tabular}{|c|c|c|c|c|}
\hline Variabel & Indikator & r hitung & r table & Keterangan \\
\hline \multirow{4}{*}{$\begin{array}{c}\text { Komitmen } \\
\text { Organisasi }\end{array}$} & Kom 1 & 0,694 & 0,2185 & Valid \\
\cline { 2 - 5 } & Kom 2 & 0,580 & 0,2185 & Valid \\
\cline { 2 - 5 } & Kom 3 & 0,537 & 0,2185 & Valid \\
\cline { 2 - 5 } & Kom 4 & 0,481 & 0,2185 & Valid \\
\cline { 2 - 5 } & Kom 5 & 0,512 & 0,2185 & Valid \\
\cline { 2 - 5 } & Kom 6 & 0,596 & 0,2185 & Valid \\
\cline { 2 - 5 } & Kom 7 & 0,450 & 0,2185 & Valid \\
\cline { 2 - 5 } & Kom 8 & 0,518 & 0,2185 & Valid \\
\cline { 2 - 5 } & Kom 9 & 0,477 & 0,2185 & Valid \\
\cline { 2 - 5 } & Kom 10 & 0,694 & 0,2185 & Valid \\
\hline
\end{tabular}

Sumber: Hasil penelitian, 2017

Berdasarkan hasil pengujian uji validitas terhadap variabel Komitmen Organisasi (Z) yang terdiri 10 pernyataan dapat diketahui bahwa semua butir pernyataan dinyatakan valid.

\section{Uji Reliabilitas}

Uji reliabilitas digunakan menentukan apakah kuesioner tetap konsisten apabila digunakan lebih dari satu kali terhadap gejala yang sama dengan alat ukur yang sama. Reliabilitas merupakan tingkat keajegan atau dapat dipercaya (konsistensi) suatu angket, dengan kata lain sejauh mana suatu angket dapat dipercaya untuk menghasilkan skor yang ajeg atau tidak berubah-ubah (Arikunto, 2010: 87). Uji statistic Cronbach Alpha $(\alpha)$ digunakan untuk menguji tingkatreliable suatu variabel. Suatu variabel dikatakan reliable jika nilai Cronbach Alpha $(\alpha)>0,60$. 
Instrument dikatakan reliabel jika mempunyai tingkat keandalan lebih dari atau sama dengan 0,60. Perhitungan uji reliabilitas dilakukan dengan program statistik (Arikunto, 2013: 276). Hasil uji Reliabilitas instrumen disajikan pada Tabel 6 berikut ini.

Tabel 6 Hasil Uji Reliabilitas

\begin{tabular}{|l|c|c|}
\hline \multicolumn{1}{|c|}{ Variabel } & $\begin{array}{c}\text { Cronbach's } \\
\text { Alpha }\end{array}$ & Keterangan \\
\hline $\begin{array}{l}\text { Kepemimpinan } \\
\text { Transformasional }\end{array}$ & 0,758 & Reliabel \\
\hline $\begin{array}{l}\text { OCB (Organizational } \\
\text { CitizhensipBehavior) }\end{array}$ & 0,843 & Reliabel \\
\hline Kepuasan Kerja & 0,783 & Reliabel \\
\hline Komitmen Organisasi & 0,751 & Reliabel \\
\hline
\end{tabular}

Sumber: Hasil penelitian, 2017

Dari hasil uji reliabilitas tersebut dapat diketahui bahwa nilai Cronbach's Alpha untuk masing-masing variabel.Nilai Cronbach's Alpha yang dihasilkan diatas 0,60 sehingga dapat disimpulkan bahwa variabel yang digunakan reliabel.

\section{Uji Multikolinieritas}

Uji multikolinieritasdilakukan untuk menguji apakah dalam model regresi ditemukan adanya korelasi antara variabel independen.Model regresi yang baik seharusnya tidak terjadi korelasi antara variabel independen.Pengujian ada tidaknya multikolinieritas dalam model regresi dapat dilihat dengan nilai tolerance dan nilai VIF (Variance Inflation Factor). Nilai yang umum digunakan untuk menunjukkan multikolinieritas yaitu nilai tolerance $\leq 0,10$ atau nilai VIF $\geq 10$ (Ghozali, 2009). Jika nilai VIF tidak lebih dari 10 dan nilai tolerance tidak kurang dari 0,1 maka dapat dikatakan terbebas dari multikolinieritas. Berikut ini adalah hasil uji multikolinieritas yang dilakukan terhadap variabel penelitian:

\section{Coefficients $^{\mathrm{a}}$}

Tabel 7 Hasil uji multikolinieritas

\begin{tabular}{|cl|c|c|}
\hline \multirow{2}{*}{} & \multirow{2}{*}{ Model } & \multicolumn{2}{|c|}{ Collinearity Statistics } \\
\cline { 2 - 4 } & Tolerance & VIF \\
\hline 1 & (Constant) & & \\
& KEPTRANS & .463 & 2.160 \\
& OCB & .606 & 1.651 \\
& KOM & .587 & 1.705 \\
\hline
\end{tabular}

a. Dependent Variable: ABS_RES1

Sumber: Hasil penelitian, 2017 
Berdasarkan uji multikolinieritas yang dilakukan terhadap variabel kepemimpinan transformasional $\left(\mathrm{X}_{1}\right)$, OCB (Organizational Citizenship Behavior) $\left(\mathrm{X}_{2}\right)$, komitmen organisasional (Z) dan kepuasan kerja (Y) menunjukkan bahwa tidak ada variabel independen yang memiliki nilai tolerance kurang dari 0,10 yang berarti tidak ada korelasi antarvariabel independen yang nilainya lebih dari 95\%. Hasil perhitungan nilai Variance Inflation Factor (VIF) juga menunjukkan tidak ada variabel independen yang memiliki nilai VIF lebih dari 10. Maka kesimpulan yang diperoleh bahwa tidak ada Multikolinieritas antar variabel independen dalam model regresi yang digunakan dalam penelitian ini.

\section{Uji Heteroskedastisitas}

Uji heteroskedastisitas dilakukan dengan menggunakan uji gletjer yaitu dengan membandingkan signifikansi setiap variabel independen.Apabila nilai signifikansi yang dihasilkan pada setiap variabel $\leq 0,05$ maka mengindikasikan terjadi heteroskedastisitas. Sebaliknya jika signifikansi yang dihasilkan $\geq 0,05$, maka tidak terjadi heteroskedastisitas. Berikut ini adalah hasil uji heteroskedastisitas yang dilakukan terhadap variabel penelitian:

\section{Coefficients $^{\mathrm{a}}$}

\section{Tabel 8 Hasil uji heteroskedastisitas metode gletjer}

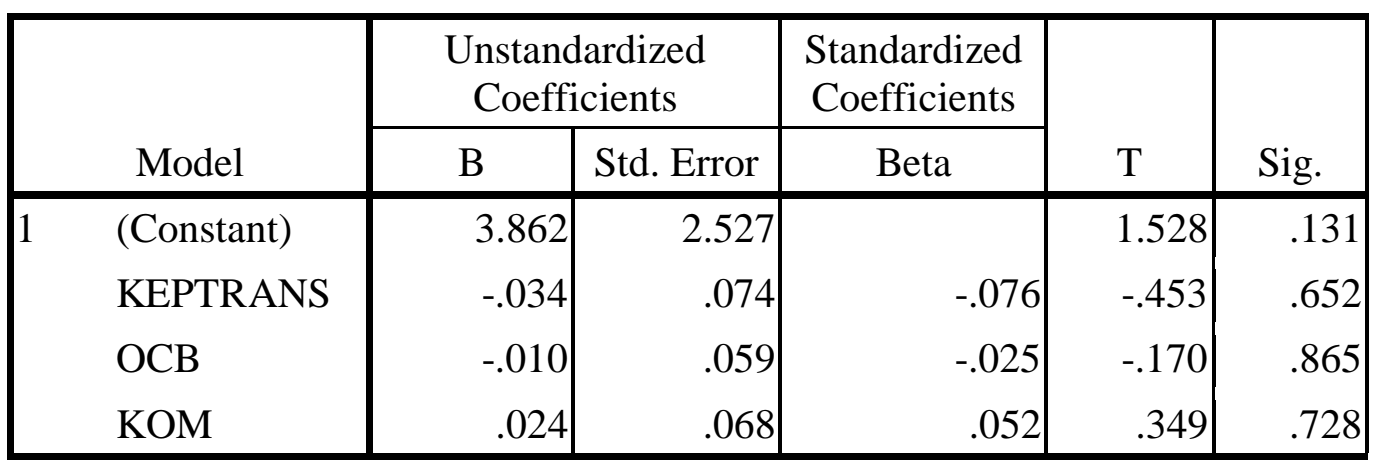

a. Dependent Variable: ABS_RES1

Sumber : Hasil penelitian, 2017

Berdasarkan hasil uji heteroskedastisitas melalui uji gletjer dapat diketahui bahwa nilai signifikansi pada variabel kepemimpinan transformasional $\left(\mathrm{X}_{1}\right)$, OCB (Organizational Citizenship Behavior) $\left(\mathrm{X}_{2}\right)$, dan Komitmen Organisasi $(\mathrm{Z})$ lebih tinggi dibandingkan dengan nilai signifikansi $(0,05)$ maka tidak terjadi heteroskedastisitas. Berikut ini adalah gambar hasil uji heteroskedastisitas adalah sebagai berikut: 


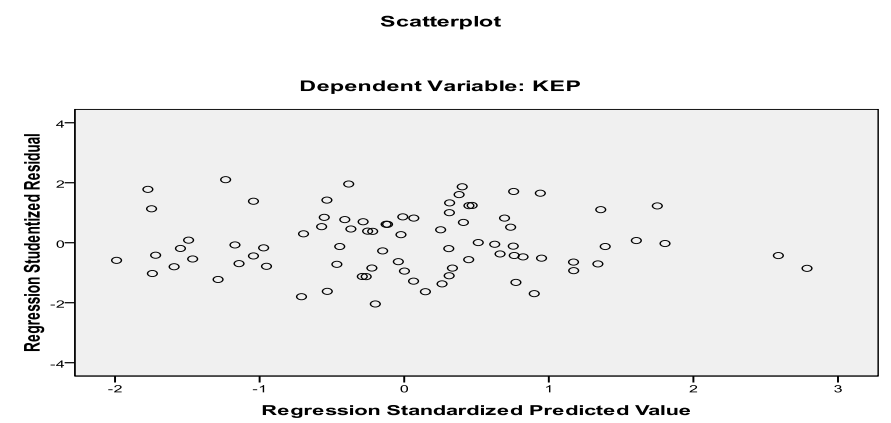

\section{Uji Normalitas}

Gambar 1 Hasil pengujian heteroskedastisitas

Uji asumsi ini akan menguji data variabel bebas (X) dan data variabel terikat (Y) pada persamaan regresi yang dihasilkan, apakah berdistribusi normal atau berdistribusi tidak normal. Persamaan regresi dikatakan baik jika mempunyai data variabel bebas dan data variabel terikat berdistribusi mendekati normal atau normal sama sekali (Sunyoto, 2009:84). Dasar pengambilan keputusan dalam uji normalitas: Jika nilai signifikansi lebih dari 0,05 maka data tersebut tidak berdistribusi normal. Uji ini dilakukan dengan cara melakukan uji normalitas Kolmogorov-Smirnov (I-Sample K-S) dengan bantuan Software SPSS 22,0 for windows. Berikut ini adalah hasil uji normalitas yang dilakukan terhadap variabel penelitian:

Tabel 9 Hasil uji normalitas metode One-Sample Kolmogorov-Smirnov Test

One-Sample Kolmogorov-Smirnov Test

\begin{tabular}{|c|c|c|c|c|c|c|}
\hline & & KEPTRANS & OCB & KOM & KEP & $\begin{array}{c}\text { Unstandardize } \\
\text { d Residual }\end{array}$ \\
\hline \multicolumn{2}{|l|}{$\mathrm{N}$} & 81 & 81 & 81 & 81 & 81 \\
\hline \multirow{3}{*}{$\begin{array}{l}\text { Normal } \\
\text { Parameters }\end{array}$} & Mean & 48.1481 & 40.172 & 38.358 & 28.148 & .0000000 \\
\hline & & & & & & \\
\hline & Std. Deviation & 4.05928 & $\begin{array}{r}4.4966 \\
4\end{array}$ & $\begin{array}{r}3.9601 \\
4\end{array}$ & $\begin{array}{r}3.6814 \\
1\end{array}$ & 3.30177262 \\
\hline \multirow{3}{*}{$\begin{array}{l}\text { Most Extreme } \\
\text { Differences }\end{array}$} & Absolute & .090 & .083 & .132 & .100 & .078 \\
\hline & Positive & .090 & .083 & .092 & .100 & .078 \\
\hline & Negative & -.055 & -.062 & -.132 & -.085 & -.050 \\
\hline \multicolumn{2}{|c|}{ Kolmogorov-Smirnov Z } & .806 & .749 & 1.191 & .901 & .705 \\
\hline \multicolumn{2}{|c|}{ Asymp. Sig. (2-tailed) } & .534 & .629 & .117 & .392 & .703 \\
\hline
\end{tabular}

a. Test distribution is Normal.

b. Calculated from data.

Sumber : Hasil penelitian, 2017

Dari data output SPSS 22,0for windows diatas dapat dilihat bahwa nilai Asymp. Sig. (2tailed) sebesar 0,703 lebih besar dari 0,05, sehingga data dapat dikatakan berdistribusi normal. Hasilanalisis regresi linier dengan grafik normal P-P Plot terhadap residual error 
model regresi diperoleh sudah menunjukkan adanya pola grafik yang normal, yaituadanya sebaran titik yang berada tidak jauh dari garis diagonal.

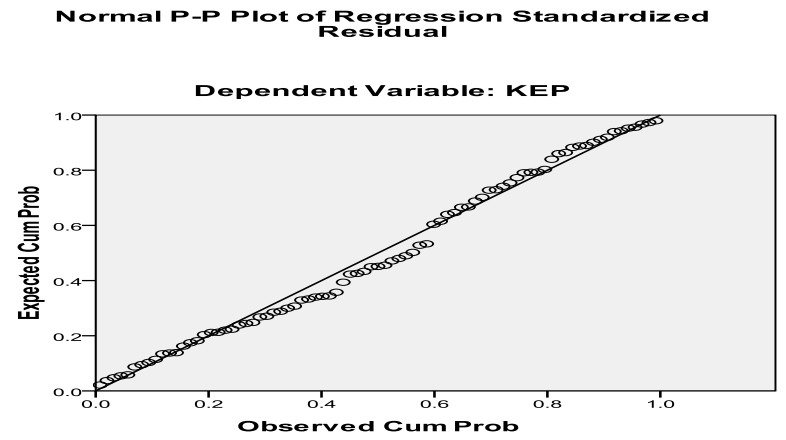

\section{Gambar 2 Hasil P-P Plot pengujian normalitas}

Hasil pengujian tersebut menunjukkan bahwa titik-titik berada tidak jauhdari garis diagonal. Hal ini berarti bahwa model regresi tersebut sudahberdistribusi normal.

Hasilanalisis regresi linier dengan histogram terhadap residual error model regresi diperoleh sudah menunjukkan adanya pola histogram yang normal.Berikut merupakan pola histogram uji Normalitas pada penelitian ini.

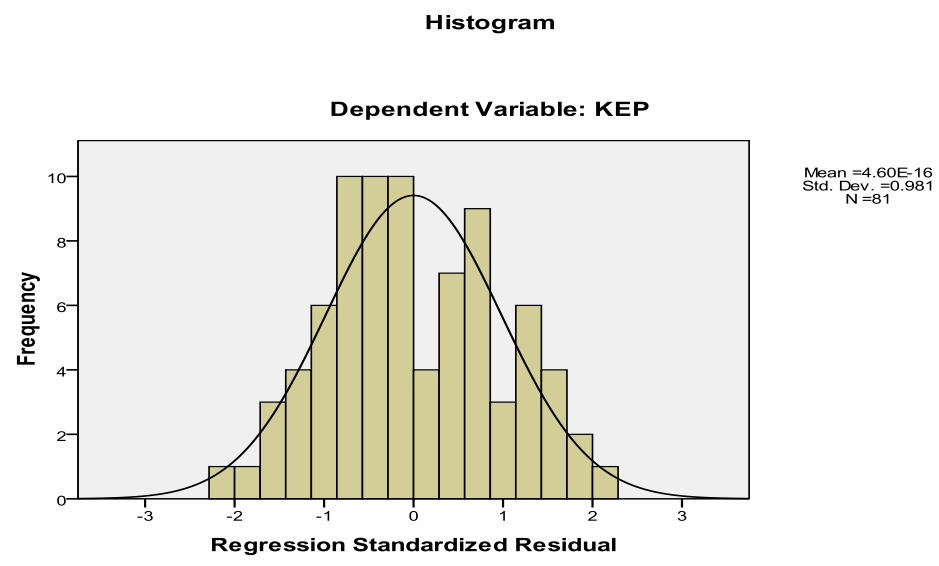

\section{Gambar 3 Hasil histogram pengujian normalitas}

\section{Uji Hipotesis}

Pengujian hipotesis dalam penelitian ini pada dasarnya menggunakan dua teknik dasar, yaitu teknik analisis regresi linear berganda dan teknik analisis jalur yang merupakan penjabaran dari analisis regresi linear berganda.Analisis regresi linear berganda digunakan untuk melakukan uji hipotesis pertama, kedua, ketiga, keempat, kelima, dan keenam.Selanjutnya, untuk teknik analisis jalur digunakan untuk menguji hipotesis ketujuh.

Untuk mempermudah dalam melakukan perhitungan pengujian hipotesis digunakan istilah atau singkatan sebagai berikut: 


$\begin{array}{lll}\text { KEPTRANS } & = & \text { Kepemimpinan Transformasional }\left(\mathrm{X}_{1}\right) \\ \mathrm{OCB} & = & \text { Organizational Citizenship Behavior }\left(\mathrm{X}_{2}\right) \\ \mathrm{KEP} & = & \text { Kepuasan Kerja }(\mathrm{Y}) \\ \mathrm{KOM} & = & \text { Komitmen Organisasi }(\mathrm{Z})\end{array}$

Pengujian hipotesis pada penelitian ini menggunakan teknik analisis berikut ini.

1) Analisis Regresi Linear Berganda

a) Koefisien Determinan $\mathrm{R}^{2}$

b) Uji F (Uji Signifikansi Simultan)

c) Uji T (Uji Signifikansi Parsial)

2) Analisis Jalur (Path Analysis) dan Uji Sobel (Uji Efek Mediasi)
a) Analisis Jalur (Path Analysis)
b) Uji Sobel (Uji Efek Mediasi)

\section{Analisis Regresi Linear Berganda}

Berdasarkan perumusan masalah penelitian,maka diperoleh hasil menggunakan multiple linear regressionanalysis seperti terlihat pada Tabel 10 berikut ini:

Tabel 10 Hasil uji regresi linear berganda

Coefficients $^{\mathrm{a}}$

\begin{tabular}{|c|c|c|c|c|c|c|}
\hline & & \multicolumn{2}{|c|}{$\begin{array}{c}\text { Unstandardized } \\
\text { Coefficients }\end{array}$} & $\begin{array}{l}\text { Standardized } \\
\text { Coefficients }\end{array}$ & \multirow[b]{2}{*}{$\mathrm{T}$} & \multirow[b]{2}{*}{ Sig. } \\
\hline \multicolumn{2}{|c|}{ Model } & B & Std. Error & Beta & & \\
\hline \multirow[t]{4}{*}{1} & (Constant) & 11.604 & 4.642 & & 2.500 & .015 \\
\hline & KEPTRANS & .424 & .136 & .467 & 3.110 & .003 \\
\hline & OCB & .099 & .108 & .120 & .916 & .362 \\
\hline & KOM & -.204 & .124 & -.219 & -1.643 & .104 \\
\hline
\end{tabular}

a. Dependent Variable: KEP

Sumber : Hasil penelitian, 2017

Berdasarkan Tabel 10 makadapat dibuat persamaan sebagai berikut:

$$
Y=11,604+0,424 X_{1}+0,099 X_{2}-0,204 Z+4,642
$$

Persamaan regresi dapat dijelaskan sebagai berikut:

(1) Konstant 11,604 menunjukan bahwa terdapat kepuasan kerja karyawan (Y) di PT. PLN (Rayon) Aek Kanopan tanpa ada variabel lain yang mempengaruhi.

(2) Koefisien regresi variabcl Kepemimpinan Transformasional $\left(\mathrm{X}_{1}\right)$ mempunyai pengaruh positif terhadap variabel Kepuasan KerjaKaryawan (Y) pada PT. PLN (Rayon) 
Aekkanopan dengan nilai sebesar 0,424 yangberarti kepemimpinan transformasional $\left(\mathrm{X}_{1}\right)$ meningkat maka kepuasan kerja karyawan (Y) pada PT. PLN (Rayon) Aek Kanopan juga akan meningkat.

(3) Koefisien regresi variabel $\mathrm{OCB}\left(\right.$ Organizational Citizenship Behavior) $\left(\mathrm{X}_{2}\right)$ mempunyai pengaruh positif terhadap Kepuasan Kerja Karyawan (Y) pada PT.PLN (Rayon) Aek Kanopan dengan nilai sebesar 0,099 yang berarti OCB(Organizational Citizenship Behavior) $\left(\mathrm{X}_{2}\right)$ meningkat maka kepuasan kerja karyawan (Y) pada PT. PLN (Rayon) Aek Kanopan juga akan meningkat.

(4) Koefisien regresi variabel komitmen organisasi (Z) mempunyai pengaruh negatif terhadap kepuasan kerjakaryawan (Y) pada PT. PLN (Rayon) Aek Kanopan dengan nilai - 0,204 yang berarti komitmen organisasi $(\mathrm{Z})$ meningkat maka kepuasan kerja karyawan (Y) pada PT. PLN (Rayon) Aek Kanopan juga akan meningkat.

\section{Koefisien Determinan $\mathbf{R}^{2}$}

Hasil koefisien determinasi dapat dilihat pada Tabel 11 berikut:

Tabel 11 Hasil koefisien determinasi $\mathbf{R}^{2}$ Model Summary ${ }^{\text {b }}$

\begin{tabular}{|l|c|r|c|c|c|}
\hline Model & $\mathrm{R}$ & R Square & $\begin{array}{c}\text { Adjusted R } \\
\text { Square }\end{array}$ & $\begin{array}{c}\text { Std. Error of } \\
\text { the Estimate }\end{array}$ & $\begin{array}{c}\text { Durbin- } \\
\text { Watson }\end{array}$ \\
\hline 1 & $.442^{\mathrm{a}}$ & .196 & .164 & 3.36548 & 1.749 \\
\hline
\end{tabular}

a. Predictors: (Constant), KOM, OCB, KEPTRANS

b. Dependent Variable: KEP

Sumber : Hasil penelitian, 2017

Nilai R (koefisien determinasi) adalah sebesar 0.442.Nilai $\mathrm{R}$ berada dalam kisaran antara (-1) dan 1, sehingga nilai sebesar 0.442termasukmempunyai korelasi yang erat karena berada dalam kisaran tersebut.

Nilai $\mathrm{R}^{2}$ (R square) sebesar 0.196 dengan Adjusted Rsquare adalah sebesar 0.164 atau $16,40 \%$, memberi makna bahwa pengaruhvariabel yang diuji memiliki pengaruh sebesar 19,60\% terhadap variabel kepuasan kerja (Y),sedangankan 80,40\% dipengaruhi oleh variabel lain yang tidak diteliti dalam penelitian ini.

\section{Uji F (Uji Signifikansi Simultan)}

Hasil uji signifikansi simultan dapat dilihat dari Tabel 12berikut ini: 
Tabel 12 Hasil uji signifikansi simultan

ANOVA $^{b}$

\begin{tabular}{|l|r|r|r|c|c|}
\hline Model & Sum of Squares & Df & Mean Square & F & \multicolumn{1}{c|}{ Sig. } \\
\hline $1 \quad$ Regression & 212.086 & 3 & 70.695 & 6.242 & $.001^{\mathrm{a}}$ \\
Residual & 872.136 & 77 & 11.326 & & \\
Total & 1084.222 & 80 & & & \\
\hline
\end{tabular}

a. Predictors: (Constant), KOM, OCB, KEPTRANS

b. Dependent Variable: KEP

sumber : Hasil penelitian, 2017

(1) Tingkat signifikan

Tingkat signifikansi yang digunakan adalah $0,05(\alpha=5 \%)$ pada tabel 4.14 , tingkat signifikansi sebesar 0,001 atau sebesar 0,01\% artinya nilai signifikansi dibawah 0,05 .

(2) Menentukan $F_{\text {tabel }}$

Dengan menggunakan standar signifikan $(\alpha=5 \%) \mathrm{Df}_{1}$ dapat ditentukan dengan persamaan berikut : $\mathrm{Df}_{1}=\mathrm{k}$ (jumlah variabel bebas + terikat $)-1$; artinya $\mathrm{Df}_{1}=$ 4-1=3. Dan $\mathrm{Df}_{2}$ dapat ditentukan dengan persamaan berikut $: \mathrm{Df}_{2}=\mathrm{n}$ (jumlah observasi/sampel pembentuk regresi) - $\mathrm{k}$; maka $\mathrm{Df}_{2}=81-4=77$. Jadi nilai $\mathrm{F}_{\text {tabel }}$ dapat dilihat pada tabel $\mathrm{F}$ pada kolom 3 baris ke 77 adalah sebesar 2,723.

(3) Membandingkan $F_{\text {hitung }}$ dengan $F_{\text {tabel }}$

Pada tabel 4.14 dapat dilihat nilai $\mathrm{F}_{\text {hitung }}$ adalah 6,242.Jika dibandingkan dengan $F_{\text {tabel }}$ yakni 2,723 maka secara signifikan nilai $F_{\text {hitung }}$ lebih besar dari $F_{\text {tabel }}(6,242>$ $2,723)$.

Berdasarkan hasil uji signifikansi simultan (uji F), dimana tingkat signifikan yang diperoleh lebih kecil yakni 0,001 dari standar signifikan 5\% $(0,05)$ dan perbandingan antara $F_{\text {hitung dan }} F_{\text {tabel, dimana }} F_{\text {hitung }}$ sebesar 6,242 lebih besar dari $F_{\text {tabel }} 2,723$, maka dapat disimpulkan bahwa secara simultan variabel Kepemimpinan Transformasional $\left(\mathrm{X}_{1}\right)$, variabel OCB (Organizational Citizenship Behavior) $\left(\mathrm{X}_{2}\right)$, dan variabel Komitmen Organisasi $(\mathrm{Z})$ memiliki pengaruh yang signifikan terhadap variabel Kepuasan Kerja (Y).

\section{Uji T (Uji Signifikansi Parsial)}

Uji T (Uji Signifikansi Parsial) digunakan untuk menguji secara parsial apakah variable Kepemimpinan Transformasional $\left(\mathrm{X}_{1}\right)$ berpengaruh terhadap variabel Kepuasan Kerja (Y), variabel OCB (Organizational Citizenship Behavior) $\left(\mathrm{X}_{2}\right)$ berpengaruh terhadap variabel 
Kepuasan Kerja (Y), dan variabel Komitmen Organisasi (Z) berpengaruh terhadap variabel Kepuasan Kerja (Y). Hasil uji signifikansi parsial (Uji T) dapat dilihat pada Tabel 13 berikut ini:

\section{Coefficients $^{\mathrm{a}}$}

Tabel 13 Hasil uji signifikansi parsial

\begin{tabular}{|c|c|c|c|c|c|c|}
\hline & \multirow[b]{2}{*}{ Model } & \multicolumn{2}{|c|}{$\begin{array}{l}\text { Unstandardized } \\
\text { Coefficients }\end{array}$} & \multirow{2}{*}{$\begin{array}{c}\text { Standardized } \\
\text { Coefficients } \\
\text { Beta } \\
\end{array}$} & \multirow[b]{2}{*}{$\mathrm{T}$} & \multirow[b]{2}{*}{ Sig. } \\
\hline & & B & Std. Error & & & \\
\hline \multirow[t]{4}{*}{1} & (Constant) & 11.604 & 4.642 & & 2.500 & .015 \\
\hline & KEPTRANS & .424 & .136 & .467 & 3.110 & .003 \\
\hline & OCB & .099 & .108 & .120 & .916 & .362 \\
\hline & KOM & -.204 & .124 & -.219 & -1.643 & .104 \\
\hline
\end{tabular}

a. Dependent Variable: KEP

Sumber : Hasil penelitian, 2017

Berdasarkan hasil uji parsial untuk variabel Kepemimpinan Transformasional $\left(\mathrm{X}_{1}\right)$ diperoleh $\mathrm{t}_{\text {hitung }}$ sebesar 3,110 dengan nilai signifikansi 0,003 < 0,05 maka Ho ditolak dan Ha diterima. Hal ini menunjukkan bahwa secara parsial $\mathrm{H}_{1}$ yang menyatakan bahwa ada pengaruh Kepemimpinan Transformasional $\left(\mathrm{X}_{1}\right)$ terhadap Kepuasan Kerja Karyawan $(\mathrm{Y})$ diterima. Berdasarkan hasil uji parsial untuk variabel OCB (Organizational Citizenship Behavior) $\left(\mathrm{X}_{2}\right)$ diperoleh $\mathrm{t}_{\text {hitung }}$ sebesar 0,916 dengan nilai signifikansi 0,362 > 0,05 maka Ho diterima dan Ha ditolak. Hal ini menunjukkan bahwa secara parsial $\mathrm{H}_{2}$ yang menyatakan bahwa ada pengaruh OCB (Organizational Citizenship Behavior) $\left(\mathrm{X}_{2}\right)$ terhadap Kepuasan Kerja (Y) ditolak. Berdasarkan hasil uji parsial untuk variabel Komitmen Organisasi (Z) diperoleh t hitung sebesar -1,643 dengan nilai signifikansi sebesar 0,104 > 0,05 maka Ho diterima dan Ha ditolak. Hal ini menunjukkan bahwa secara parsial $\mathrm{H}_{3}$ yang menyatakan bahwa ada pengaruh variable Komitmen Organisasional (Z) terhadap variabel Kepuasan Kerja (Y) ditolak.

\section{2) Analisis Jalur (Path Analysis) dan Uji Sobel (Uji Efek Mediasi)}

\section{a) Analisis Jalur (Path Analysis)}

Analisis jalur digunakan untuk melihat pengaruh dari variabel eksogen terhadap variabel endogen melalui variabel eksogen lainnya dan mengukur pengaruh langsung dan tidak langsung dari suatu variabel terhadap variabel lain. Setelah melakukan uji normalitas dan homogenitas, maka penelitian ini dilanjutkan dengan melakukan analisis jalur. 
(1) Pengaruh Kepemimpinan Transformasional $\left(X_{1}\right)$ Dan OCB (Organizational Citizenship Behavior) $\left(\mathrm{X}_{2}\right)$ Terhadap Komitmen Organisasional Karyawan (Z) Pada PT. PLN (Rayon) Aek Kanopan

Berikut ini akan dibahas mengenai pengaruh variabel kepemimpinan transformasional $\left(\mathrm{X}_{1}\right)$ dan OCB (Organizational Citizenship Behavior) $\left(\mathrm{X}_{2}\right)$ terhadap komitmen organisasional karyawan (Z) pada PT. PLN (Persero) Rayon Aek Kanopan secara simultan dan parsial.

Tabel 14 Interpretasi koefisien jalur variabel kepemimpinan transformasional $\left(\mathrm{X}_{1}\right)$ dan OCB (Organizational Citizenship Behavior) $\left(\mathrm{X}_{2}\right)$ terhadap komitmen organisasi $(\mathbf{Z})$

\begin{tabular}{|c|c|c|c|c|c|}
\hline Variabel & $\begin{array}{c}\text { Koefisien } \\
\text { jalur }\end{array}$ & $\begin{array}{c}\text { T } \\
\text { hitung }\end{array}$ & Sig & F & sig \\
\hline $\begin{array}{c}\text { Kepemimpinan } \\
\left.\text { transformasional( } \mathrm{X}_{1}\right)\end{array}$ & 0,560 & 5,065 & 0,000 & & \\
\hline $\begin{array}{c}\text { OCB(Organizational } \\
\text { Citizenship Behavior }) \\
\left(\mathrm{X}_{2}\right)\end{array}$ & 0,122 & 1,105 & 0,273 & 0,000 \\
\hline
\end{tabular}

Dependent Variable: Komitmen Organisasi(Z)

Sumber : Hasil penelitian, 2017

Berdasarkan Tabel 14 maka dapat dibuat persamaan sebagai berikut:

$\mathrm{KOM}(\mathrm{Z})=\operatorname{KEPTRANS}\left(\mathrm{X}_{1}\right)+\mathrm{OCB}\left(\mathrm{X}_{2}\right)+\mathrm{e}$

$Z=0,560 X_{1}+0,122 X_{2}+4,145$

(1). Berdasarkan analisis yang dilakukan maka diperoleh nilai signifikansi uji F sebesar 0,000. Hal ini berarti hipotesis kedua dalam penelitian ini diterima (Ha diterima).Artinya kepemimpinan transformasional $\left(\mathrm{X}_{1}\right)$ dan $\mathrm{OCB}($ Organizational Citizenship Behavior) $\left(\mathrm{X}_{2}\right)$ berpengaruh signifikan terhadap komitmen organisasional (Z)karyawan pada PT.PLN(Rayon) Aek Kanopan.

(2). Berdasarkan analisis yang dilakukan maka diperoleh nilai koefisien jalur secara parsial masing-masing variabel kepemimpinan transfomasional $\left(\mathrm{X}_{1}\right)$ dan OCB (Organizational Citizenship Behavior) $\left(\mathrm{X}_{2}\right)$ terhadap komitmen organisasi (Z) adalah sebagai berikut :

(a). Pengaruh Kepemimpinan Transformasional $\left(\mathrm{X}_{2}\right)$ Terhadap Komitmen Organisasi Karyawan (Z).

Koefisien jalur $\mathrm{P}\left(\mathrm{X}_{1} \mathrm{Z}\right)=0,560$ dengan nilai signifikansi sebesar 0,000. Jika nilai signifikansi dibandingkan dengan tingkat signifikan yang digunakan pada 
penelitian ini $(\alpha=0,05)$ maka terbukti bahwa nilai signifikansi lebih kecil dari tingkat signifikannya $(0,000<0,05)$. Hal ini berarti koefisien jalur memperlihatkan bahwa kepemimpinan transformasional berpengaruh positif dan signifikan terhadap komitmen organisasional karyawan pada PT. PLN (Rayon) Aek Kanopan.Jika kepemimpinan transformasional semakin baik maka komitmen organisasional karyawan juga cenderung meningkat.

(b). Pengaruh OCB (Organizational Citizenship Behavior) $\left(\mathrm{X}_{2}\right)$ Terhadap Komitmen Organisasional Karyawan (Z).

Koefisien jalur $\mathrm{P}\left(\mathrm{X}_{2} \mathrm{Z}\right)=0,122$ dengan nilai signifikansi sebesar 0,273. Jika nilai signifikansi dibandingkan dengan tingkat signifikan yang digunakan pada penelitian ini $(\alpha=0,05)$ maka terbukti bahwa nilai signifikansi lebih besar dari tingkat signifikannya $(0,273<0,05)$. Hal ini berarti koefisien jalur memperlihatkan bahwa OCB (Organizational Citizenship Behavior) tidak memiliki pengaruh positif dan signifikan terhadap komitmen organisasional karyawan pada PT. PLN (Rayon) Aek Kanopan.Jika OCB (Organizational Citizenship Behavior) buruk maka komitmen organisasional karyawan juga cenderung menurun.

(3) Pengaruh variabel lain (Ze)

$$
\mathrm{P}(\mathrm{Ze})=\sqrt{1-\mathrm{R}^{2}\left(\mathrm{YX}_{1} \mathrm{X}_{2}\right)}
$$

$=\sqrt{1-0,413}$

$=\sqrt{0,587}=0,766=76,60 \%$

(2) Pengaruh Kepemimpinan Transformasional $\left(X_{1}\right)$, OCB $($ Organizational Citizenship Behavior) $\left(\mathbf{X}_{2}\right)$, Dan Komitmen Organisasi $(\mathrm{Z})$ Terhadap Kepuasan Kerja (Y) Karyawan Pada PT. PLN (Rayon) Aek Kanopan

Berikut ini akan dibahas mengenai pengaruh variabel kepemimpinan transformasional $\left(\mathrm{X}_{1}\right)$, OCB (Organizational Citizenship Behavior) $\left(\mathrm{X}_{2}\right)$, dan komitmen organisasi (Z) terhadap kepuasan kerja karyawan (Y) pada PT. PLN (Rayon) Aek Kanopan secara simultan dan parsial. 
Tabel 15

Interpretasi koefisien jalur variabel kepemimpinan transformasional $\left(\mathrm{X}_{1}\right)$, variabel OCB(Organizational Citizenship Behavior) $\left(\mathrm{X}_{2}\right)$, dan komitmen organisasi $(\mathrm{Z})$ terhadap kepuasan kerja karyawan (Y)

\begin{tabular}{|c|c|c|c|c|c|}
\hline Variabel & Koefisien Jalur & T Hitung & Sig & $\mathbf{F}$ & Sig \\
\hline $\begin{array}{l}\text { Kepemimpinan } \\
\text { Transformasional }\left(\mathrm{X}_{1}\right)\end{array}$ & 0,467 & 3,110 & 0,003 & \multirow{3}{*}{6,242} & \multirow{3}{*}{0,001} \\
\hline $\begin{array}{l}\mathrm{OCB}(\text { Organizational } \\
\text { Citizenship Behavior })\left(\mathrm{X}_{2}\right)\end{array}$ & 0,120 & 0,916 & 0,362 & & \\
\hline $\begin{array}{l}\text { Komitmen Organisaional } \\
\text { Karyawan }(\mathrm{Z})\end{array}$ & $-0,219$ & $-1,643$ & 0,104 & & \\
\hline
\end{tabular}

Dependent Variable : Kepuasan Kerja(Y)

Sumber : Hasil penelitian, 2017

Berdasarkan Tabel 16 maka dapat dibuat persamaan sebagai berikut :

$$
\begin{aligned}
\operatorname{KEP}(\mathrm{Y}) & =\operatorname{KEPTRANS}\left(\mathrm{X}_{1}\right)+\mathrm{OCB}\left(\mathrm{X}_{2}\right)+\mathrm{KOM}(\mathrm{Z})+\mathrm{e} \\
\mathrm{Y} & =0,467 \mathrm{X}_{1}+0,120 \mathrm{X}_{2}-0,219 \mathrm{Z}+4,642
\end{aligned}
$$

(1) Berdasarkan analisis yang dilakukan maka diperoleh nilai signifikansi uji $F$ sebesar 0,001. Hal ini berarti hipotesis kedua dalam penelitian ini diterima (Ha diterima). Artinya Kepemimpinan Transformasional $\left(\mathrm{X}_{1}\right)$, OCB (Organizational Citizenship Behavior) $\left(\mathrm{X}_{2}\right)$, dan Komitmen Organisasi $(\mathrm{Z})$ berpengaruh signifikan terhadap Kepuasan Kerja karyawan (Y) pada PT. PLN (Rayon) Aek Kanopan.

(2) Berdasarkan analisis yang dilakukan maka diperoleh nilai koefisien jalur secara parsial masing-masing variabel Kepemimpinan Transfomasional $\left(\mathrm{X}_{1}\right)$, OCB (Organizational Citizenship Behavior) $\left(\mathrm{X}_{2}\right)$, dan Komitmen Organisasi $(\mathrm{Z})$ terhadap Kepuasan Kerja (Y) adalah sebagai berikut:

(a) Pengaruh Kepemimpinan Transformasional $\left(\mathrm{X}_{1}\right)$ terhadap Kepuasan Kerja Karyawan $(\mathrm{Y})$. Koefisien jalur $\mathrm{P}\left(\mathrm{YX}_{1}\right)=0,467$ dengan nilai signifikansi sebesar 0,003. Jika nilai signifikansi dibandingkan dengan tingkat signifikan yang digunakan pada penelitian ini $(\alpha=0,05)$ maka terbukti bahwa nilai signifikansi lebih kecil dari tingkat signifikannya $(0,003<0,05)$. Hal ini berarti koefisien jalur memperlihatkan bahwa kepemimpinan transformasional berpengaruh positif dan signifikan terhadap kepuasan kerja karyawan pada PT. PLN (Rayon) Aek Kanopan.Jika kepemimpinan transformasional semakin baik maka kepuasan kerja juga cenderung meningkat. 
(b) Pengaruh OCB (Organizational Citizenship Behavior) $\left(\mathrm{X}_{2}\right)$ terhadap Kepuasan Kerja karyawan (Y)

Koefisien jalur $\mathrm{P}\left(\mathrm{YX}_{2}\right)=0,120$ dengan nilai signifikansi sebesar 0,362. Jika nilai signifikansi dibandingkan dengan tingkat signifikan yang digunakan pada penelitian ini $(\alpha=0,05)$ maka terbukti bahwa nilai signifikansi lebih besar dari tingkat signifikannya $(0,362>0,05)$. Hal ini berarti koefisien jalur memperlihatkan bahwa OCB (Organizational Citizenship Behavior) tidak berpengaruh positif dan signifikan terhadap kepuasan kerja karyawan pada PT. PLN (Rayon) Aek Kanopan.Jika OCB (Organizational Citizenship Behavior)semakin buruk maka kepuasan kerja juga cenderung menurun.

(c) Pengaruh Komitmen Organisasi (Z) terhadap Kepuasan Kerja (Y)

Koefisien jalur $\mathrm{P}(\mathrm{YZ})=-0,219$ dengan nilai signifikansi sebesar 0,104. Jika nilai signifikansi dibandingkan dengan tingkat signifikan yang digunakan pada penelitian ini $(\alpha=0,05)$ maka terbukti bahwa nilai signifikansi lebih besar dari tingkat signifikannya $(0,104>0,05)$. Hal ini berarti koefisien jalur memperlihatkan bahwa komitmen organisasi tidak berpengaruh positif dan signifikan terhadap kepuasan kerja karyawan pada PT. PLN (Rayon) Aek Kanopan.Jika komitmen organisasi semakin buruk maka kepuasan kerja juga cenderung menurun.

(3) Pengaruh variabel lain (Ze)

$$
\begin{aligned}
& \mathrm{PZe}=\sqrt{1-\mathrm{R}^{2}\left(\mathrm{YX}_{1} \mathrm{X}_{2} \mathrm{Z}\right)} \\
& =\sqrt{1-0,196} \\
& =\sqrt{0,804} \\
& =0,896=89,60 \%
\end{aligned}
$$

b) Uji Sobel (Uji Efek Mediasi)

(1) Pengaruh Langsung(Direct Effect), Tidak Langsung(Indirect Effect), dan Pengaruh Total(Total Effect)

(a) Pengaruh Langsung (Direct Effect atau DE)

Berdasarkan hasil penelitian antara variable independent dengan variable dependent maka ringkasan pengaruh langsung (direct effect) sebagai berikut :

i. Pengaruh langsung kepemimpinan transformasional terhadap komitmen organisasi karyawan $\left(\mathrm{X}_{1} \rightarrow \mathrm{Z}\right)=0,560$ 
ii. Pengaruh langsung OCB (Organizational Citizenship Behavior) terhadap komitmen organisasi karyawan $\left(\mathrm{X}_{2} \rightarrow \mathrm{Z}\right)=0,122$

iii. Pengaruh langsung kepemimpinan transformasional terhadap kepuasan kerja karyawan $\left(\mathrm{X}_{1} \rightarrow \mathrm{Y}\right)=0,467$

iv. Pengaruh langsung OCB (Organizational Citizenship Behavior) terhadap kepuasan kerja karyawan $\left(\mathrm{X}_{2} \rightarrow \mathrm{Y}\right)=0,120$

v. Pengaruh langsung komitmen organisasi terhadap kepuasan kerja karyawan $(\mathrm{Z} \rightarrow \mathrm{Y})=-0,219$

\section{(b) Pengaruh Tidak Langsung (Indirect Effect atau IE)}

Berdasarkan hasil penelitian antara variable independent dengan variable dependent maka ringkasan pengaruh tidak langsung (indirect effect)sebagai berikut :

i. Pengaruh tidak langsung kepemimpinan transformasional terhadap kepuasan kerja melalui komitmen organisasi karyawan $\left(\mathrm{X}_{1} \rightarrow \mathrm{Z} \rightarrow \mathrm{Y}\right)=(0,467 \times(-0,219))=$ $-0,102273$

ii. Pengaruh tidak langsung OCB(Organizational Citizenship Behavior) terhadap kepuasan kerja melalui komitmen organisasi karyawan $\left(\mathrm{X}_{2} \rightarrow \mathrm{Z} \rightarrow \mathrm{Y}\right)=(0,120$ $\times(-0,219))=-0,02628$

\section{(c) Pengaruh Total (Total Effect atau TE)}

Berdasarkan hasil penelitian antara variable independent dengan variable dependent maka ringkasan pengaruh tidak langsung (indirect effect)sebagai berikut :

i. Pengaruh tidak langsung kepemimpinan transformasional terhadap kepuasan kerja melalui komitmen organisasi karyawan $\left(\mathrm{X}_{1} \rightarrow \mathrm{Z} \rightarrow \mathrm{Y}\right)=(0,560+(-0,219))=0,341$

ii. Pengaruh tidak langsung OCB(Organizational Citizenship Behavior) terhadap kepuasan kerja melalui komitmen organisasi karyawan $\left(\mathrm{X}_{2} \rightarrow \mathrm{Z} \rightarrow \mathrm{Y}\right)=($ $0,122+(-0,219))=-0,097$

Interpretasi dari hasil pengaruh langsung (direct effect), pengaruh tidak langsung (indirect effect) dan pengaruh total (total effect) akan memiliki arti yang penting untuk menentukan strategi dalam meningkatkan kepuasan kerja karyawan pada PT. PLN (Persero) rayon Aek Kanopan. 
Tabel 17

Hasil analisis koefisien jalur, kontribusi pengaruh langsung(direct effect), pengaruh tidak langsung(indirect effect), dan pengaruh total(total effect)

\begin{tabular}{|l|c|c|c|c|c|}
\hline \multirow{2}{*}{$\begin{array}{c}\text { Variable } \\
\text { Independent } \\
\text { Terhadap Variable } \\
\text { Dependent }\end{array}$} & \multirow{2}{*}{$\begin{array}{c}\text { Koef. } \\
\text { Jalur }\end{array}$} & Direct & Indirect & Total & \multirow{2}{*}{$\mathbf{R}^{\mathbf{2}}$} \\
\cline { 5 - 7 } $\mathrm{X}_{1}$ terhadap Z & 0,560 & 0,560 & - & & - \\
\hline $\mathrm{X}_{2}$ terhadap Z & 0,122 & 0,122 & - & & - \\
\hline $\mathrm{X}_{1}$ dan $\mathrm{X}_{2}$ terhadap Z & - & - & - & - & 0,413 \\
\hline $\mathrm{X}_{1}$ terhadap Y & 0,467 & 0,467 & $-0,102273$ & 0,341 & - \\
\hline $\mathrm{X}_{2}$ terhadap Y & 0,120 & 0,120 & $-0,02628$ & $-0,097$ & - \\
\hline $\mathrm{Z}_{\text {terhadap Y }}$ & $-0,219$ & $-0,219$ & - & & - \\
\hline $\begin{array}{l}\mathrm{X}_{1}, \mathrm{X}_{2,} \text { dan Z } \\
\text { terhadap Y }\end{array}$ & - & - & - & - & 0,196 \\
\hline
\end{tabular}

Sumber : Hasil penelitian, 2017

Berdasarkan Tabel 17 tersebut, maka hasil penelitian secara objektif bahwa:

i. Kepemimpinan transformasional $\left(\mathrm{X}_{1}\right)$ terhadap komitmen organisasional karyawan (Z) memiliki pengaruh positif dan signifikan terhadap tinggi rendahnya komitmen organisasional karyawan $(\mathrm{Z})$. Besar pengaruh kepemimpinan transformasional $\left(\mathrm{X}_{1}\right)$ yang secara langsung berpengaruh terhadap komitmen organisasional karyawan (Z) sebesar $(0,560)^{2}=0,3136$ atau $31,36 \%$. Sedangkan pengaruh variabel lainnya diluar kepemimpinan transformasional $(100 \%-31,36 \%)=68,64 \%$.

ii. OCB (Organizational Citizenship Behavior) $\left(\mathrm{X}_{2}\right)$ terhadap komitmen organisasional karyawan (Z) memiliki pengaruh positif dan signifikan terhadap tinggi rendahnya komitmen organisasional karyawan (Z). Besar pengaruh OCB (Organizational Citizenship Behavior $)\left(\mathrm{X}_{2}\right)$ yang secara langsung berpengaruh terhadap komitmen organisasional karyawan $(\mathrm{Z})$ sebesar $(0,122)^{2}=0,014884$ atau $1,48 \%$. Sedangkan pengaruh variabel lainnya diluar kepemimpinan transformasional $(100 \%-1,48 \%)=$ $98,5116 \%$.

iii. Kepemimpinan transformasional $\left(\mathrm{X}_{1}\right)$ dan OCB (Organizational Citizenship Behavior $)\left(\mathrm{X}_{2}\right)$ terhadap komitmen organisasional karyawan $(\mathrm{Z})$ memiliki pengaruh positif dan signifikan terhadap tinggi rendahnya komitmen organisasional karyawan (Z). Besar pengaruh kepemimpinan transformasional $\left(\mathrm{X}_{1}\right)$ dan OCB (Organizational Citizenship Behavior $)\left(\mathrm{X}_{2}\right)$ yang secara langsung berpengaruh terhadap komitmen 
organisasional karyawan (Z) sebesar 0,413 atau 41,30\%. Sedangkan pengaruh variabel lainnya diluar kepemimpinan transformasional $(100 \%-41,30 \%)=58,70 \%$.

iv. Kepemimpinan transformasional $\left(\mathrm{X}_{1}\right)$ terhadap kepuasan kerja karyawan (Y) memiliki pengaruh positif dan signifikan terhadap tinggi rendahnya kepuasan kerja karyawan $(\mathrm{Y})$. Besar pengaruh kepemimpinan transformasional $\left(\mathrm{X}_{1}\right)$ yang secara langsung berpengaruh terhadap kepuasan kerja karyawan (Y) sebesar $(0,467)^{2}=$ 0,218089 atau $21,80 \%$. Sedangkan pengaruh variabel lainnya diluar kepemimpinan transformasional $(100 \%-21,80 \%)=78,20 \%$.

v. OCB (Organizational Citizenship Behavior) $\left(\mathrm{X}_{2}\right)$ terhadap kepuasan kerja karyawan (Y) memiliki pengaruh positif dan signifikan terhadap tinggi rendahnya kepuasan kerja karyawan (Y). Besar pengaruh OCB (Organizational Citizenship Behavior) $\left(\mathrm{X}_{2}\right)$ yang secara langsung berpengaruh terhadap kepuasan kerja karyawan (Z) sebesar $(0,120)^{2}=0,0144$ atau $1,44 \%$. Sedangkan pengaruh variabel lainnya diluar kepemimpinan transformasional $(100 \%-1,44 \%)=98,56 \%$.

vi. Komitmen Organisasional (Z) terhadap kepuasan kerja karyawan (Y) memiliki pengaruh positif dan signifikan terhadap tinggi rendahnya kepuasan kerja karyawan (Y). Besar pengaruh komitmen organisasional (Z) yang secara langsung berpengaruh terhadap kepuasan kerja karyawan (Y) sebesar $(-0,219)^{2}=0,047961$ atau $4,79 \%$. Sedangkan pengaruh variabel lainnya diluar kepemimpinan transformasional (100\% $-4,79 \%)=95,21 \%$.

vii. Kepemimpinan transformasional $\left(\mathrm{X}_{1}\right)$, OCB (Organizational Citizenship Behavior) $\left(\mathrm{X}_{2}\right)$, dan komitmen organizational karyawan $(\mathrm{Z})$ terhadap kepuasan kerja karyawan (Y) memiliki pengaruh positif dan signifikan terhadap tinggi rendahnya kepuasan kerja karyawan. Besar pengaruh kepemimpinan transformasional $\left(\mathrm{X}_{1}\right)$, OCB (Organizational Citizenship Behavior) $\left(\mathrm{X}_{2}\right)$, dan komitmen organisasional karyawan (Z) yang secara langsung berpengaruh terhadap kepuasan kerja karyawan (Y) sebesar 0,196 atau 19,60\%. Sedangkan pengaruh variabel lainnya diluar kepemimpinan transformasional $(100 \%-19,60 \%)=80,40 \%$. 


\section{KESIMPULAN DAN SARAN}

\section{Kesimpulan}

Berdasarkan hasil analisis data, maka kesimpulan yang diperoleh dari penelitian ini sebagai berikut:

1. Hasil analisis diperoleh bahwa variabel Kepemimpinan Transformasional ( $\left.\mathrm{X}_{1}\right)$ berpengaruh positif dan signifikan terhadap Kepuasan Kerja karyawan.

2. OCB (Organizational Citizenship Behavior) berpengaruh positif dan signifikan terhadap Kepuasan Kerja karyawan.

3. Kepemimpinan Transformasional berpengaruh positif dan signifikan terhadap Komitmen Organisasi.

4. OCB (Organizational Citizenship Behavior) berpengaruh positif dan signifikan terhadap Komitmen Organisasi.

5. Hasil analisis diperoleh bahwa variabel Kepemimpinan Transformasional dan OCB (Organizational Citizenship Behavior) berpengaruh positif dan signifikan terhadap Kepuasan Kerja Karyawan.

6. Variabel Komitmen Organisasi tidak memediasi variabel Kepemimpinan Transformasional dan variabel OCB (Organizational Citizenship Behavior) terhadap Kepuasan Kerja Karyawan.

\section{Saran}

Berdasarkan hasil kesimpulan tersebut, maka dapat diambil saran sebagai berikut:

1. PT. PLN (Rayon) Aekkanopan diharapkan agar meningkatkan komitmen organisasi kepada karyawan. Peningkatan komitmen organisasi dapat dilakukan dengan cara menjadikan visi-misi perusahaan sebagai suatu yang karismatik, melestarikan tradisi perusahaan, menjalin komunikasi dua arah di perusahaan, semua unsur di dalam perusahaan sebagai komunitas serta membangun nilai-nilai yang didasarkan pada prinsip kebersamaan (get together) serta diharapkan agar meningkatkan OCB (Organizational Citizenship Behavior) kepada karyawan serta pimpinan. Peningkatan OCB (Organizational Citizenship Behavior) dapat dilakukan dengan cara meningkatkan suasana hati atau mood, persepsi terhadap dukungan organisasional, persepsi terhadap kualitas interaksi atasan-bawahan, masa kerja, budaya dan iklim organisasi. 
2. Bagi penelitian selanjutnya, berdasarkan teori kepemimpinan transformasional, OCB (Organizational Citizenship Behavior), dan komitmen organisasional merupakan faktor penting dalam memberikan kontribusi pembentukan kepuasan kerja, maka peneliti selanjutnya diharapkan tetap mempertimbangkan kepemimpinan transformasional, OCB (Organizational Citizenship Behavior), dan komitmen organisasional sebagai faktor pembentukan kepuasan kerja karyawan. Selain itu diharapkan untuk dapat mengembangkan hasil dari penelitian ini dengan menambahkan variabel lain yang dapat mempengaruhi kepuasan kerja seperti kompensasi, motivasi kerja, kondisi kerja, stress kerja, gaya kepemimpinan, perilaku organisasi, kecerdasan intelektual dan emosional, pelatihan dan pengembangan, dan sebagainya. Mengembangkan penelitian ini dengan menggunakan alat analisis yang lain seperti SEM pada program software AMOS, CFA pada program LISREL dan sebagainya untuk mengembangkan penelitian ini selanjutnya. Selain itu perlu dilakukan penelitian lebih lanjut dalam mengkaji pengaruh kepemimpinan transformasional dan OCB (Organizational Citizenship Behavior) terhadap kepuasan kerja dengan komitmen organisasi sebagai perantara atau variabel intervening untuk skala yang lebih besar baik dari sisi sampel maupun dari jenis perusahaannya.

\section{REFERENSI}

\section{Buku}

Arikunto, Suharsini. 2010. "Prosedur Penelitian Suatu Pendekatan Praktis". Jakarta: Rineka Cipta.

.2013. "Prosedur Penelitian Suatu Pendekatan Praktis". Jakarta: Rineka

Cipta.

Andreas, Lako. 2004. “Kepemimpinan dan Kinerja Organisasi Isu Teori dan Solusi”. Yogyakarta: Amara Books.

Anas, Sudijono.2006. “Pengantar Statistik Pendidikan”. Jakarta: PT. Raja Grafindo Persada.

Bass, Bernard M, dan Riggio, Ronald E. 2005. “Transformational Leadership, Learning and Employability”.

Bohrnstedt, Herbert M. Jr. 1981. “Social Statistics”.Tokyo : McGraw Hill.

Creswell, Jhon W. 2013. “Research Design :Pendekatan Kualitatif, Kuantitatif Dan Mixed”. Terj. Achmad Fawaid. Yogyakarta : Pustaka Belajar.

Furqon. 2001. "Statistika Terapan Untuk Penelitian”. Bandung : Alfabeta. 
Ghozali, Imam. 2010. "Metodologi Penelitian (edisi kelima)". Semarang: Universitas Diponegoro.

.2011. “Aplikasi Analisis Multivariate Dengan Program IBM SPSS 19 (edisi kelima). Semarang: Universitas Diponegoro.

Iskandar. 2008. "Metode Penelitian Pendidikan Dan Sosial (Kuantitatif dan Kuantitatif)”. Jakarta: Gaung Persada Pers.

Jackson, Schuler, Werner.2011. "Pengelolaan Sumber Daya Manusia 2". Edisi kesepuluh.Terjemahan. Jakarta: Salemba Empat.

Margono. 2010. “Metodologi Penelitian Pendidikan”. Jakarta: Rineka Cipta.

Moleong, L. J. 2008. “Metodologi Penelitian Kualitatif”. Bandung: Remana Rosdakarya. .2012. “Metodologi Penelitian Kualitatif'. Bandung: PT. Remana Rosdakarya.

Meyer, J.P and Allen, N.J(1997). "Commitment In The Workplace: Theory Research And Application, Sage Publications. Thousand Oakes, C. A.

Netter, John, William Wasserman, Michael H. Kurtner. 1987. "Statistics, A Toll For The Social Science”. Boston : Duxbury

Robbins, Stephen dan Coulter, Mary.2010.“Manajemen”. Jakarta: Gramedia.

Riduwan, Kuncoro, A.E. 2009.“Cara Menggunkan dan Memakai Analisis Jalur”. Bandung: Alfabeta.

.2009. "Rumus dan Data Dalam Analisis Statistik". Bandung: Alfabeta.

Robbins, Stepen, P. dan Judge. Timothy. A. 2008. “Organizational Behavior”.Jakarta: Salemba Empat.

Robbins, Stepen P. 2007. “Manajemen”.Terjemahan. T.Hermaya. Jakarta: Prenhalindo.

Robbins, Stepen, P dan Judge, Timothy. A. Judge. 2009. “Organizational Behavior”.Three Edition, USA: Pearson International Edition, Prentice-Hall.

Rutherford, Robert D dan Minja Kim Choe. 1993. "Statistical Model For Causal Analysis". New York : John Wiley \& Son. Inc.

Sani, Abdullah. R. 2010. “Metode Penelitian Pendidikan Pendekatan Kualitatif, Kuantitatif, dan $R \& D$ ”. Surabaya: Insan Cindekia.

Sugiyono. 2013. "Statistik Untuk Penelitian". Bandung: CV. Alfabeta. 
2013. "Metode Penelitian Kuantitatif, Kualitatif, dan $R \& D$ \&. Bandung: CV. Alfabeta.

. 2013. "Metode Penelitian Bisnis". Bandung: CV. Alfabeta.

Sukmadinata, Nana Syardih. 2011. “Metode Penelitian Pendidikan”. Bandung: PT. Remana Rosdakarya.

Sutrisno, Edy. 2013. “Manajemen Sumber Daya Manusia”. Edisi Pertama. Jakarta: Kencana. Wibowo. 2012. "Manajemen Kinerja (Edisi ketiga)". Jakarta: Rajawali Pers.

Yukl, Gary. 2010. “Kepemimpinan Dalam Organisasi (Edisi kelima)”. Jakarta: PT. Indeks.

Zainuddin dan Ghodang.Hironymus. 2015. “aplikasi analisis jalur”. Bandung: Citapustaka media.

\section{Artikel Online}

www.managementstudyguide.com

pmcounseling. 2011. "Sharing Innovative Business Research and Practices What Is Transformational Leadership?" Retrieved sep 25 2013. From http://pmcounseling. Wordpress.com/2011/12/17/transformational_leadership/.

\section{Jurnal}

Batool, Bano, Fakhra. 2013. “An Empirical Study On Effect Of Transformational Leadership On Organizational Commitment In The Banking Sector Of Pakistan”. IOSR Journal Of Business and Management. Vol. 8,Issue 2 (Jan-Feb 2013) PP 38-44.

Bushra, Fatima, et al. 2011. "Effect Of Transformational Leadership On Employees' Job Satisfaction and Organizational Commitment In Banking Sector Of Lahore (Pakistan)". International Journal Of Business and Social Sciense, University Of The PUNJAB, Vol. 2. No. 18 : October 2011.

Chang.S.C and Lee.M.S. 2006. "Relationship Among Personality Traits, Job Characteristic, Job Satisfaction, And Organizational Commitment: An Empirical Study In Taiwan”. The Business Rewiew. Vol.6.No.1. PP. 201-207.

Hartiti, Tri. 2013. "Efektivitas Model Kepemimpinan Transformasional Terhadap Peningkatan SoftskillPerawat Pelaksana". Jurnal Disertasi Doktoral Keperawatan Universitas Indonesia. 
Hartiti, Tri. 2013. "Peningkatan Softskill Perawat Melalui Kepemimpinan Transformasional Kepala Ruang Pada RS. Swasta Di Semarang. Jurnal Manajemen Keperawatan, Fakultas Keperawatan dan Ilmu Kesehatan, Universitas Muhammadiyah Semarang.

Khan, Sofiah. 2015. "The Mediating Effect Of Organization Commitment In The Organization Culture, Leadership And Organization Justice Relationship With Organizational Citizenship Behavior: A Study Of Academics In Private Higher Learning Institutions In Malaysia”. International Journal Of Recent Advances In Organizational Behavior And Decisions Scinces (IJRAOB), University Tunku Abdul Rahman, Vol.2, No.18: October 2011.

Noermijati, dkk. 2014. "The Effect Of Perceived Organization Support And Job Satisfaction Toward Organizational Citizenship Behavior Mediated By Organizational Commitment (A Study On Teacher Of Islamic Boarding School In Malang)”. International Journal Of Business And Behavior Sciences. Fakultas Ekonomi dan Bisnis. Universitas Brawijaya. Vol.4. No.2.February 2014.

Organ, D.W dan Ryan, K.1995. “A Meta-Analysis Review Of Attitudinal And Dispositional Predictors Of Organizational Citizenship Behavior, Personal Psychology, Vol.48. no.4.PP.775-800.

Prabowo, Adityo. 2014. “Analisis Pengaruh Kepemimpinan Transformasional Dan Kepuasan Kerja Terhadap OCB (Organizational Citizenship Behavior) dengan Komitmen Organisasi Sebagai Variabel intervening (studi pada perawat RSUP. Dr. Kariadi, Semarang)”. Skripsi.Fakultas Ekonomi dan Bisnis. Universitas Diponegoro.

Podsakoff, P.M.Mackenzie, S.B., Paine, J.B, dan Bachrach, D.G.2000. "Organizational Citizenship Behavior: A Critical Review Of The Theoretical And Empirical Literature And Suggestions For Future Research", Journal Of Management. Vol.26. no.3.PP.513-536.

Qamar, Nida. 2012. "Job Satisfaction And Organizational Commitment As Antecedent Of Organizational Citizenship Behavior". Interdisciplinary journal of contemporary research in business(IJCRB), University Of Pakistan. Vol.4, No. 7, November 2012.

Rahmi, Maptuhah. 2014. "Pengaruh Kepemimpinan Transformasional Terhadap Organizational Citizenship Behavior Dan Komitmen Organisasional Dengan Mediasi Kepuasan Kerja(Studi Pada Guru Tetap SMA Negeri 1 Kabupaten Lombok Timur)”. Jurnal Manajemen Bisnis, Fakultas Ekonomi Universitas Udayana (UNUD). 
Shwera, J.,and Srirang, J. 2010. "Determinants Of Organizational Citizenship Behavior”. A Review Of Literature, Journal Of Management And Public Policy, Vol. 1. No.2. PP. 2736.

Sopiah. 2008. "Budaya Organisasi, Komitmen Organisasional Pimpinanan Dan Pengaruhnya Terhadap Kepuasan Kerja Dan Kinerja Karyawan Bank”. Jurnal Keuangan Dan Perbankan. Vol.12. no. 2. Mei 2008. 